\title{
Identification of Androgen Receptor Metabolic Correlome Reveals the Repression of Ceramide Kinase by Androgens
}

\author{
Laura Camacho ${ }^{1,2}$, Amaia Zabala-Letona ${ }^{1,3}$, Ana R. Cortazar ${ }^{1,3}$, Ianire Astobiza ${ }^{1}$, Asier Dominguez-Herrera ${ }^{2}$,

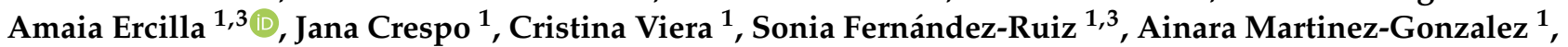 \\ Veronica Torrano ${ }^{1,2,3}$, Natalia Martín-Martín ${ }^{1,3}$, Antonio Gomez-Muñoz ${ }^{2}$ and Arkaitz Carracedo ${ }^{1,2,3,4, * \mathbb{C}}$ \\ 1 Center for Cooperative Research in Biosciences (CIC bioGUNE), Basque Research and Technology \\ Alliance (BRTA), Bizkaia Technology Park, Building 801A, 48160 Derio, Spain; lcamacho@cicbiogune.es (L.C.); \\ azabala@cicbiogune.es (A.Z.-L.); acortazar@cicbiogune.es (A.R.C.); iastobiza@cicbiogune.es (I.A.); \\ aercilla.ciberonc@cicbiogune.es (A.E.); jcrespo@cicbiogune.es (J.C.); cviera@cicbiogune.es (C.V.); \\ sfernandez@cicbiogune.es (S.F.-R.); amgonzalez@cicbiogune.es (A.M.-G.); vtorrano@cicbiogune.es (V.T.); \\ nmartin@cicbiogune.es (N.M.-M.) \\ 2 Biochemistry and Molecular Biology Department, University of the Basque Country, 48040 Bilbao, Spain; \\ asidomiherre@gmail.com (A.D.-H.); antonio.gomez@ehu.es (A.G.-M.) \\ 3 Centro de Investigación Biomédica En Red de Cáncer (CIBERONC), 28029 Madrid, Spain \\ 4 IKERBASQUE, Basque Foundation for Science, 48009 Bilbao, Spain \\ * Correspondence: acarracedo@cicbiogune.es
}

Citation: Camacho, L.;

Zabala-Letona, A.; Cortazar, A.R.; Astobiza, I.; Dominguez-Herrera, A.; Ercilla, A.; Crespo, J.; Viera, C.; Fernández-Ruiz, S.; Martinez-Gonzalez, A.; et al. Identification of Androgen Receptor Metabolic Correlome Reveals the Repression of Ceramide Kinase by Androgens. Cancers 2021, 13, 4307. https://doi.org/10.3390/ cancers 13174307

Academic Editors: Alfonso Urbanucci and Delila Gasi Tandefelt

Received: 1 June 2021

Accepted: 18 August 2021

Published: 26 August 2021

Publisher's Note: MDPI stays neutral with regard to jurisdictional claims in published maps and institutional affiliations.

Copyright: (c) 2021 by the authors. Licensee MDPI, Basel, Switzerland. This article is an open access article distributed under the terms and conditions of the Creative Commons Attribution (CC BY) license (https:// creativecommons.org/licenses/by/ $4.0 /)$.
Simple Summary: Prostate cancer cells require androgens to survive and grow. In turn, targeting androgen signaling has become a predominant therapeutic strategy in this disease. These hormones regulate a plethora of biological processes, which identification could aid the refinement of future anticancer treatments. Our aim was to uncover metabolic processes under the control of androgens, taking advantage of bioinformatics analyses using publicly accessible data in prostate cancer. We found that these hormones control the abundance of an enzyme, ceramide kinase (CERK). CERK produces ceramide-1-phosphate, a metabolite with prosurvival and migration properties. This finding suggests that antiandrogen therapies could be limited by the reactivation of this metabolic process.

Abstract: Prostate cancer (PCa) is one of the most prevalent cancers in men. Androgen receptor signaling plays a major role in this disease, and androgen deprivation therapy is a common therapeutic strategy in recurrent disease. Sphingolipid metabolism plays a central role in cell death, survival, and therapy resistance in cancer. Ceramide kinase (CERK) catalyzes the phosphorylation of ceramide to ceramide 1-phosphate, which regulates various cellular functions including cell growth and migration. Here we show that activated androgen receptor (AR) is a repressor of CERK expression. We undertook a bioinformatics strategy using PCa transcriptomics datasets to ascertain the metabolic alterations associated with AR activity. CERK was among the most prominent negatively correlated genes in our analysis. Interestingly, we demonstrated through various experimental approaches that activated AR reduces the mRNA expression of CERK: (i) expression of CERK is predominant in cell lines with low or negative AR activity; (ii) AR agonist and antagonist repress and induce CERK mRNA expression, respectively; (iii) orchiectomy in wildtype mice or mice with PCa (harboring prostate-specific Pten deletion) results in elevated Cerk mRNA levels in prostate tissue. Mechanistically, we found that AR represses CERK through interaction with its regulatory elements and that the transcriptional repressor EZH2 contributes to this process. In summary, we identify a repressive mode of AR that influences the expression of CERK in PCa.

Keywords: prostate cancer; bioinformatics; mouse models; sphingolipid metabolism; ceramide kinase 


\section{Introduction}

Hormone signaling governs the molecular activity of an important fraction of cells in our body. Steroid hormones are essential for the development and function of a wide range of tissues through the regulation of nuclear receptors, including sexual organ development and function [1-3]. In male reproductive organs, androgens activate androgen receptors (AR) to elicit a broad transcriptional program [4]. These steroids induce a conformational change in AR that promotes its dimerization, translocation to the nucleus, and association with Androgen Response Elements (ARE) in the DNA [4].

Similar to their normal counterparts, prostate cancer cells require androgen signaling to survive and proliferate [5-7]. In turn, androgen receptor and androgen synthesis represent pivotal therapeutic targets (androgen deprivation therapy or ADT), and a variety of anticancer agents targeting this hormonal program has proven to hamper prostate cancer progression [7-9]. However, resistance to androgen deprivation often emerges, leading to a form of the disease (castration-resistant prostate cancer or CRPC) that accounts for a large fraction of prostate cancer mortality [10-12]. It is therefore essential to deconstruct the molecular events that account for ADT efficacy and drug resistance.

Due to its relevance in normal and cancer cell homeostasis, the study of AR signaling has become a focus of research. Many AR targets have been identified and validated, a process that has advanced exponentially with the implementation of high throughput genomics and transcriptomics technologies [13-15]. Whereas the vast majority of AR target genes are transcriptionally activated by androgens, reports point at AR-mediated gene repression as an emerging phenomenon [16-18].

Metabolic pathways have been consistently reported among the molecular programs regulated by androgens. Androgens control the uptake and biosynthesis of different types of lipids and the metabolism of amino acids and carbohydrates [19-24]. However, a systematic analysis of metabolic routes under androgen regulation is lacking.

Sphingolipids function as second messengers and structural components essential for cell homeostasis $[25,26]$. Ceramide is at the core of this metabolic pathway, and its role in cell biology is widely accepted [26]. Whereas this metabolite activates tumor-suppressive processes, its phosphorylation and the production of ceramide-1-phosphate (C1P) induces a switch in its activity, thus promoting cell viability, proliferation, and migration [26]. Ceramide kinase (CERK) catalyzes the production of C1P and, in turn, the regulation of this enzyme is paramount in sphingolipid homeostasis [25]. Yet, our understanding of the regulation of CERK in health and disease is limited, and upstream regulatory cues need to be identified.

Here we annotate the metabolic genes that are consistently correlated with androgen receptor activity by means of a bioinformatics approach encompassing a compendium of publicly available PCa transcriptomics datasets, which we term the androgen receptor metabolic correlome. Among the regulated genes and pathways, we focus on sphingolipid metabolism and demonstrate that CERK is an AR-repressed gene. We shed light on the molecular mechanism of action of AR to repress CERK, thus expanding the information regarding the mechanism and function of androgens.

\section{Results}

To identify metabolic processes regulated by AR signaling in PCa, we undertook a bioinformatics approach (Figure 1A). First, we set out to define the gene signature that would best illustrate the activation status of AR in prostate cancer. We started from a published meta-analysis of AR signaling-associated gene expression studies, in which the authors identified a gene set that was consistently regulated by androgens in 6 different experimental studies [15]. The positive or negative transcriptional activation by AR was ascertained in that gene set with 34 genes (Table S1). Stemming from the work by Massie et al. [27], together with Cancertool [28], we could annotate these genes as induced or repressed by activated AR (Table S1). We identified 23 genes consistently activated by androgens and 8 that were repressed, whereas 3 genes were excluded from the analysis 
due to the inability to assign directionality. Of note, this shortlist contained well-known AR target genes, including kallikreins KLK2 and KLK3 [29], thus validating our bioinformatics strategy.

We built an AR activity gene expression signature based on the ratio of expression of upregulated and downregulated AR target genes, which we termed AR signature (AR Signature $=\left(\right.$ average expression of upregulated genes in $\left.\log _{2}\right)-($ average expression of upregulated genes in $\log _{2}$ ); Figure 1A). We next selected the genes identified as metabolic enzymes and transporters according to KEGG [30] and metabolic co-regulators [31,32], leading to a gene set of 2775 genes that we defined as metabolic genes. We performed correlation studies with the metabolic gene set and AR signature in 8 different PCa transcriptomics datasets containing primary tumor specimens. We selected those that exhibited a consistent correlation, meaning a direct (coefficient greater than 0.2 and $p$-value lower than 0.05 ) or inverse (coefficient lower than -0.2 and $p$-value lower than 0.05 ) correlation in more than $50 \%$ of datasets with available data for a given gene [33-40]. This correlation analysis led to a list of 223 metabolic genes consistently correlated with AR activity, that we defined as the AR metabolic correlome (Figure 1A; Table S2). As a validation of our strategy, we could confirm that the top metabolic genes directly correlated with AR activity, GPT2 and SLC45A3, are reported AR targets [41,42].

To ascertain the metabolic impact of androgen signaling, we performed gene enrichment analyses. KEGG analysis revealed a series of metabolic pathways enriched in the list of AR correlated genes (Figure 1B). We interrogated the nature and predicted impact of androgen signaling on the resulting metabolic pathways. Some of these pathways have been previously reported as androgen-regulated [19-24]. Interestingly, sphingolipid metabolism exhibited a gene expression alteration by androgens that directed the pathway towards the production of ceramide (Figure 1C). AR activity is directly correlated with the expression of enzymes that metabolize sphingolipids to produce ceramide, whereas it is inversely correlated with ceramide kinase, an enzyme that will reduce the pool of ceramide by eliciting its phosphorylation [43]. We decided to focus on this metabolic pathway for subsequent studies, owing to the little information regarding the regulation of the pathway by androgens. A summary of the correlation results of the AR signature with the mRNA expression of these enzymes in multiple PCa datasets is depicted in Figure 1D.

Correlation studies based on activity signatures represent an invaluable tool to identify genes which expression is associated with a pathway of interest. However, this information is insufficient to conclude that such genes are targets of the process under investigation as they could be altered as a secondary consequence of downstream molecular effectors. To ascertain the genes within sphingolipid metabolism that are regulated by androgens, we performed a variety of in vitro and in vivo experimental approaches. We evaluated the expression pattern of these candidate genes in a panel of prostate cell lines with known androgen signaling status. We took advantage of $K L K 3$ (the gene encoding for prostatespecific antigen, PSA) as a readout of AR activity. As reported, LNCaP, C4-2, 22RV1, and VCaP cells exhibited robust AR activity by means of KLK3 expression, whereas PC 3 and DU145 (AR-negative prostate cancer cells) or RWPE1, PWR1E, and BPH1 cells (benign prostate immortalized cells) exhibited low activity of the nuclear receptor (Figure 2A). Among the five sphingolipid metabolism genes identified in the correlome, only CERK and PLPP1 exhibited a consistent association with AR activity. PLPP1 exhibited a positive association with androgen signaling, and CERK expression was reduced in AR-expressing cells (Figure 2A and Figure S1A). Next, we manipulated the activation status of AR in vitro with selective agonists (dihydrotestosterone, DHT) or antagonists (MDV3100, Enzalutamide) [44]. The effect of these compounds on the expression of KLK3 was robust 24 hours after treatment (Figure 2B). Among the five sphingolipid metabolism genes, PLPP1 and $C E R K$ exhibited a significant time-dependent regulation of gene expression after $24 \mathrm{~h}$ with both agents, with the predicted directional consistency (Figure 2B and Figure S1B). 
A
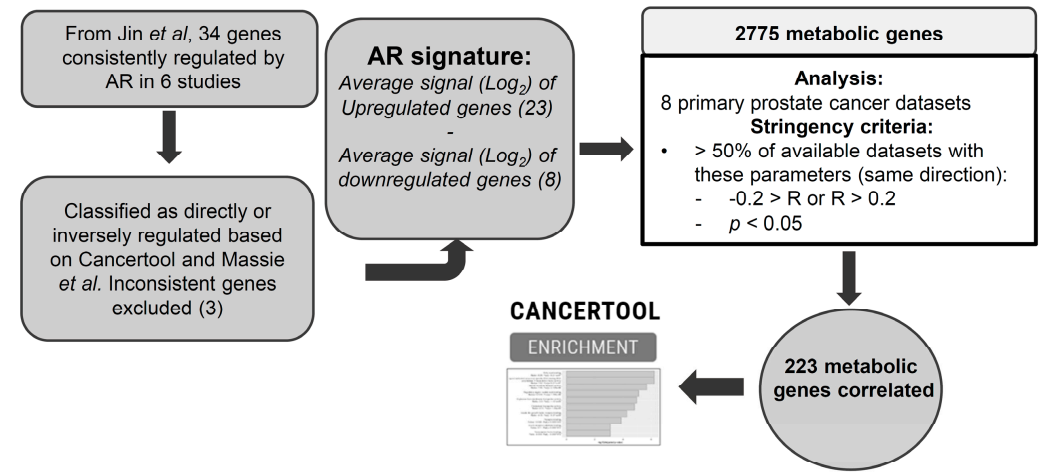

B

Biosynthesis of unsaturated fatty acids Proximal tubule bicarbonate reclamation Ether lipid metabolism
Amino sugar and nucleotide sugar Steroid biosynthesis Glycine, serine and threonine metabolism Alanine, aspartate and glutamate Fructose and mannose metabolism Cysteine and methionine metabolism Arginine and proline metabolism Sphingolipid metabolism PPAR signaling pathway Glycerophospholipid metabolism Valine, leucine and isoleucine degradation

$\%$ genes correlated within the pathwayo

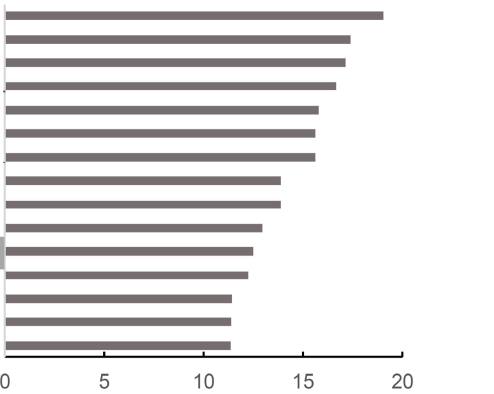

C

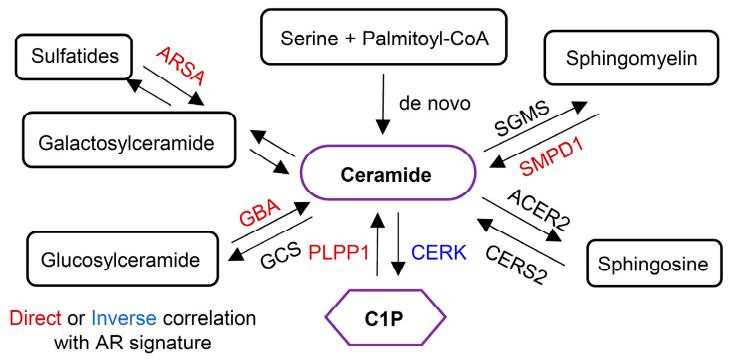

D

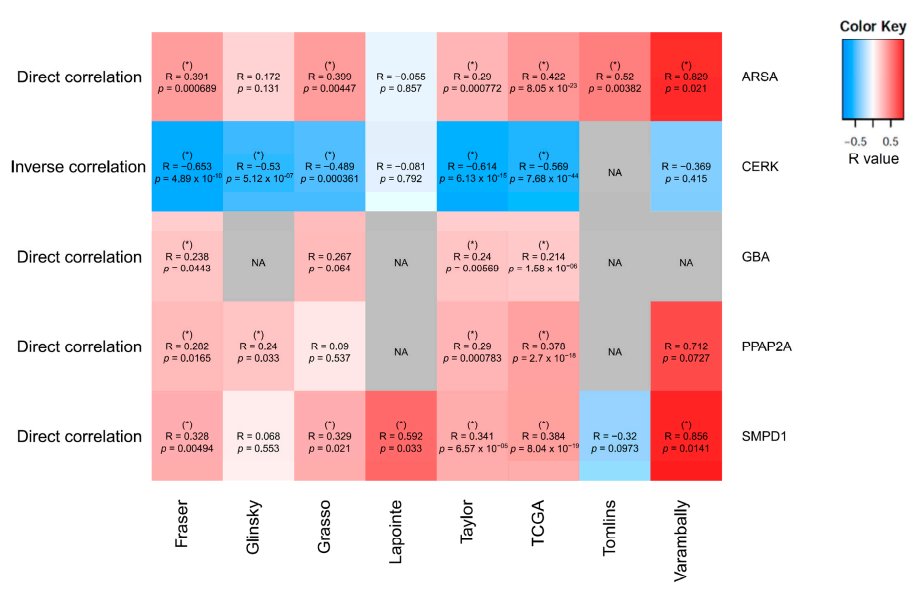

Figure 1. Sphingolipid metabolism is regulated by androgen receptor (AR). (A) Bioinformatics analysis workflow of prostate cancer patient transcriptomics datasets performed with Cancertool to identify metabolic genes correlated with androgen receptor activity. (B) KEGG pathways enrichment of AR activity-correlated metabolic genes (AR metabolic correlome). (C) Schematic ceramide biosynthetic pathway, adapted from Merscher et al. Positively and negatively correlated enzymes are highlighted in red and blue, respectively. (D) Heatmap representation of the sphingolipid metabolic genes correlated with AR signature in multiple PCa datasets encompassing primary tumors. Red and blue color intensity depict the degree of direct and inverse correlation, respectively. An asterisk is included when the correlation coefficient is greater than 0.2 or lower than -0.2 with a $p$-value lower than 0.05 . 
A
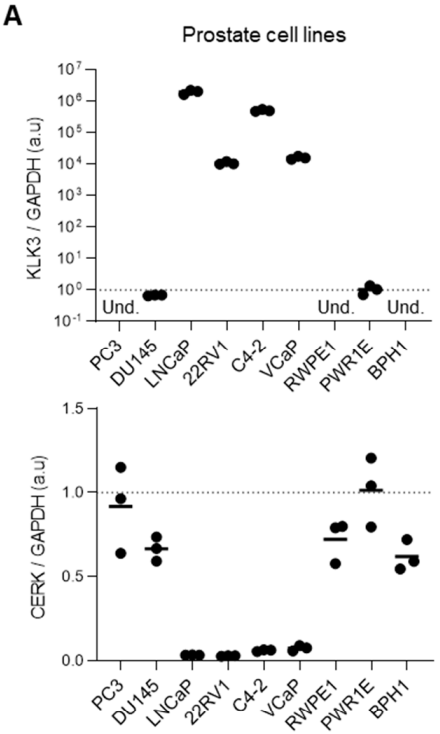

C
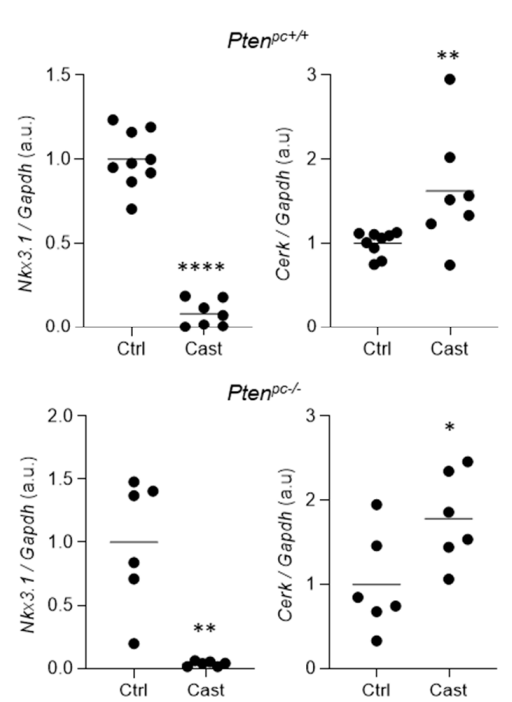

B
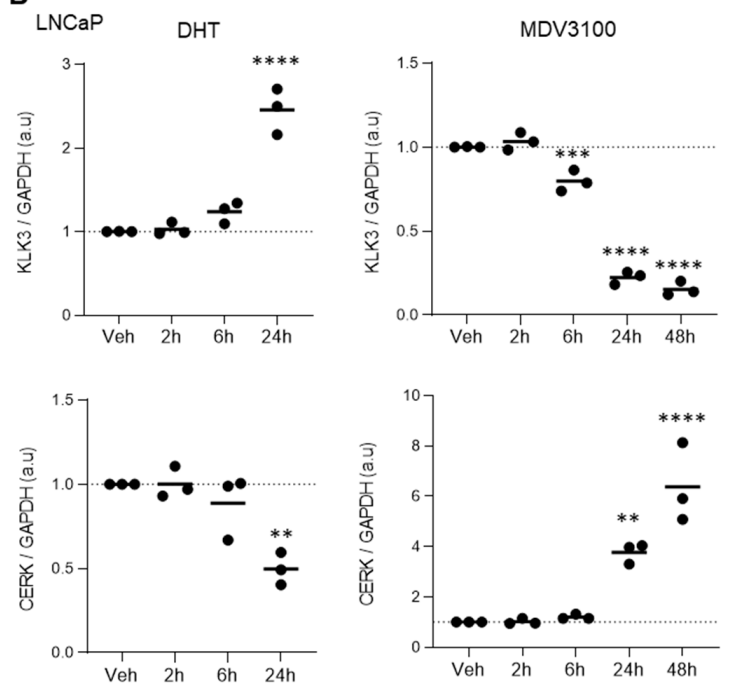

D

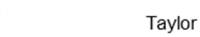
Taylor
$\mathrm{R}=-0.3359, p=9.3 \times 10^{-05}$ $\mathrm{R}=-0.4503, \rho \mathrm{A}$

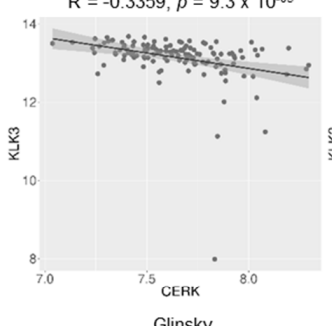
$=-0.4503, p=4.3 \times 10^{-26}$

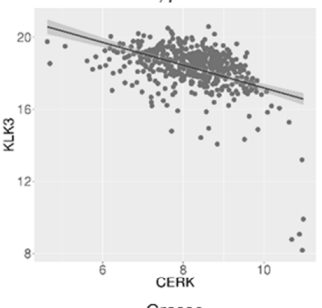
$\mathrm{R}=-0.3711, p=0.000761$

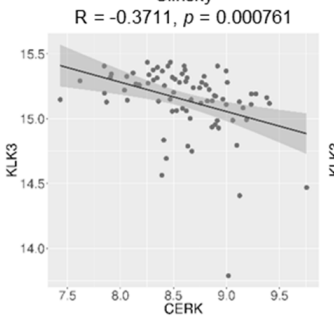
$\mathrm{R}=-0.3148, p=0.02758$

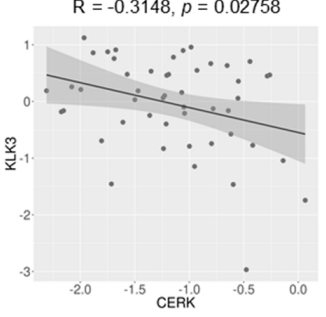

E
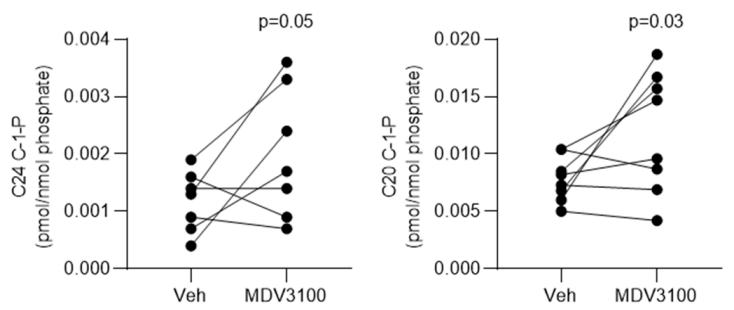

Figure 2. AR represses CERK expression. (A) Analysis of the AR target KLK3 and CERK gene expression by qRT-PCR in a panel of prostate cells ( $n=3$ independent experiments). Data were normalized to GAPDH expression. mRNA abundance was normalized to the benign cell line PWR1E. Und. stands for undetermined. (B) Analysis of KLK3 and CERK gene expression by qRT-PCR upon treatment with AR agonist (dihydrotestosterone, DHT, $10 \mathrm{nM}$, left panels) or antagonist (MDV-3100, $10 \mu \mathrm{M}$, right panels) in LNCaP cells ( $n=3$ independent experiments). Data were normalized to GAPDH expression. ANOVA and Dunnett's multiple comparisons test was performed. (C) Gene expression analysis of the AR target gene, Nkx3.1, and Cerk by qRT-PCR in prostate-specific Pten wild type in upper panels (Pten ${ }^{p c+/+}$ ) castrated at 4 months of age (Cast, $n=7$ mice) compared to control (Ctl, $n=9$ mice), and knock out mice in lower panels (Pten ${ }^{p c-/-}$, castrated at 6 months of age, $n=6$ mice per group), 6 days after performing orchiectomy. Data were normalized to GAPDH/Gapdh expression. A one-tailed Mann-Whitney test was performed. (D) Pearson correlation of CERK and KLK3 mRNA expression in the indicated PCa datasets. (E) LC/MS analysis of phosphorylated C24 and C20 ceramide species upon treatment with AR antagonist MDV-3100 (10 $\mu \mathrm{M})$ compared to vehicle (Veh). Paired t-test analyses were performed. ${ }^{*} p<0.05 ;{ }^{* *} p<0.01$; *** $p<0.001 ;{ }^{* * * *} p<0.0001$. 
Androgens control both prostate development and growth [4-6]. To corroborate the regulation of sphingolipid metabolic genes in a more complex experimental setting, we performed orchiectomy in adult male mice, in a context of normal prostate physiology (wildtype mice) or PCa (prostate-conditional Pten knockout mice). As mice do not express kallikreins, we used the androgen-dependent gene $N k \times 3.1$ to validate the loss of AR activity after castration (Figure 2C). Among the five genes, only Cerk exhibited the predicted changes in mRNA levels upon castration (Figure 2C and Figure S1C). We focused our attention on this enzyme and showed that $C E R K$ was repressed by androgen signaling in a validation set of PCa cell lines (C4-2, VCaP, and 22Rv1) (Figure S2A). Of note, CERK was less responsive to androgen regulation in 22RV1, a cell line that expresses an AR variant, and was not regulated in the AR-negative cell line PC3 (Figure S2A,B). These results are in line with the inverse correlation between the AR target $K L K 3$ and $C E R K$ in various $\mathrm{PCa}$ transcriptomics datasets (Figure 2D and Figure S2C). Overall, our results reveal CERK as a gene repressed by androgen signaling in PCa.

The regulation of CERK expression by androgens should influence the production of $\mathrm{C} 1 \mathrm{P}$. To evaluate whether AR signaling regulates CERK activity and C1P production, we measured the abundance of these metabolites in a context of AR inhibition in androgendependent LNCaP cells that exhibit low CERK expression. In agreement with the upregulation of CERK observed upon AR inhibition, we detected an increase in C20 and C24 C1P levels, but not in their non-phosphorylated ceramide counterparts (Figure 2E and Figure S3). Of note, the levels of sphingosine-1-phosphate, a different sphingolipid not phosphorylated by CERK, remained unaffected by MDV3100 (Figure S3).

To elucidate the mechanism of repression of CERK, we focused on the regulatory activity of AR. This nuclear receptor functions predominantly as a transcriptional activator. However, there are examples of genes repressed by androgen signaling $[16,17,45,46]$. We performed chromatin immunoprecipitation (ChIP) assays. We studied two potential androgen receptor binding sites (AR sites) in the proximity of the CERK gene based on a previous report (Figure 3A) [47]. Only AR site 1 exhibited significant binding to AR, and androgen stimulation significantly increased the association of the nuclear receptor to this site (Figure 3B,C). As a quality control of our assay, we gathered two results. First, we showed that androgens enhanced the binding of AR to the AR sites present in KLK3 by ChIP (Figure 3C). Second, AR binding to AR site 2 did not show enrichment in the qPCR analysis, suggesting that the assay did not have technical issues that would artificially provide binding to CERK (Figure 3B).

The repressive transcriptional activity of AR has been linked to the function of the chromatin remodeler EZH2 [45], among other factors. We hypothesized that EZH2, the functional enzymatic component of the Polycomb Repressive Complex 2, could function as a CERK repressor and that this protein would define the negative regulation of the sphingolipid metabolic gene by androgens. On the one hand, we showed that EZH2 was significantly associated with the AR-binding region in CERK AR site 1 (Figure 3D). On the other hand, we took advantage of a well-characterized inhibitor of EZH2, GSK126 [48]. Treatment with this compound in PCa cells revealed a dose-dependent de-repression of CERK (Figure 3E). Moreover, the EZH2 inhibitor partially prevented DHT-induced CERK repression, whereas it cooperated with AR antagonist MDV3100 in the activation of CERK expression (Figure 3E). Of note, this inhibitor did not exhibit a consistent effect on the regulation of the AR canonical target KLK3 (Figure S4A), in line with the non-repressive action of AR on this kallikrein. 
A

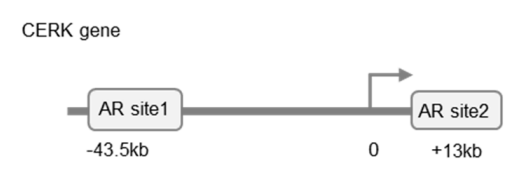

Based on Wilson et al., Sci Rep 2016

B

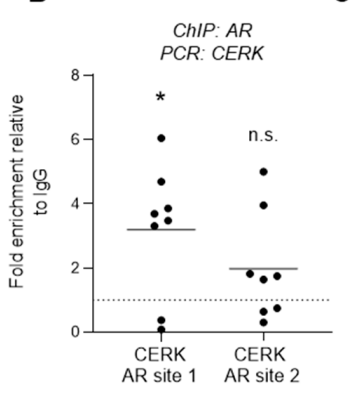

E

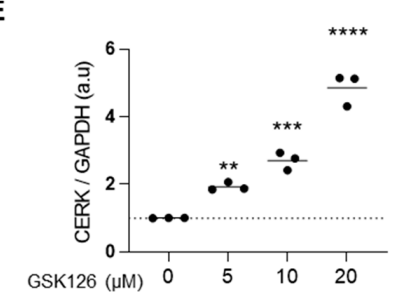

C

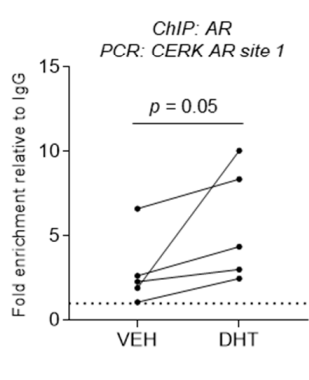

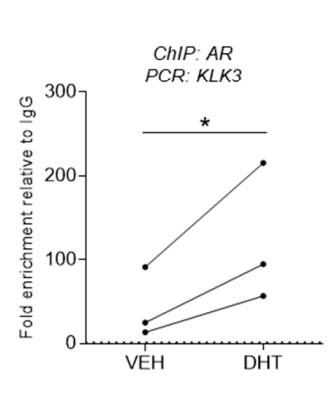

D

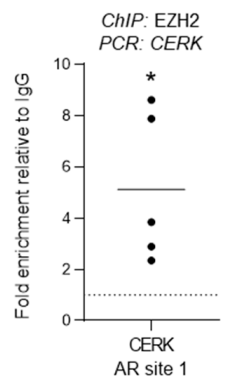

SSSS

F
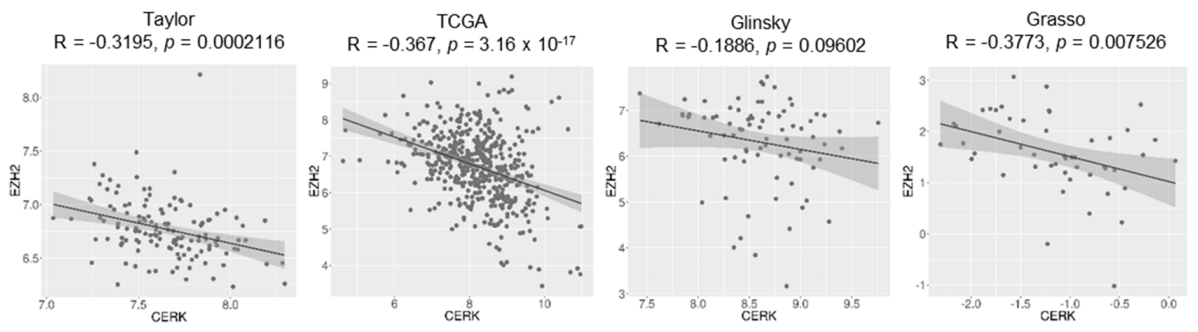

G
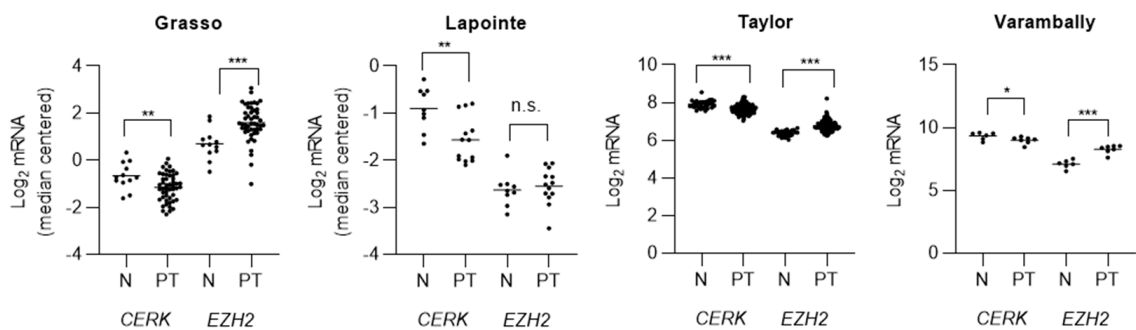

Figure 3. EZH2 cooperates with AR in eliciting CERK repression. (A) Androgen receptor binding site (AR sites) location represented on CERK gene sequence. (B) ChIP of AR on the indicated sites in LNCaP cells ( $n=8$ independent experiments). Data were normalized to IgG (negative-binding control). One-sample $t$-test. (C) ChIP of AR on CERK AR site 1 and KLK3 in LNCaP cells ( $n=3-5$ independent experiments) with and without DHT treatment $(10 \mathrm{nM})$. Data were normalized to IgG (negative-binding control). One-tail Paired $t$-test. (D) ChIP of EZH2 on AR site 1 of CERK regulatory region in LNCaP cells ( $n=5$ independent experiments). Data were normalized to IgG (negative-binding control). One-sample $t$-test. (E) Analysis of CERK gene expression by qRT-PCR upon 24-h treatment with EZH2 inhibitor GSK126 at increasing concentrations (left), in combination with DHT ( $10 \mathrm{nM}$, middle) and MDV-3100 (10 $\mu \mathrm{M}$, right) in LNCaP cells ( $n=3$ independent experiments). ANOVA with Dunnett's (left) or Tukey's (center and right) multiple comparison test. The asterisk refers to comparisons against vehicles, hash refers to comparisons against GSK and dollar refers to comparisons against DHT or MDV. (F) Pearson correlation of CERK and EZH2 mRNA expression in the indicated PCa datasets. (G) mRNA expression analysis of CERK and $E Z H 2$ in normal tissue $(\mathrm{N})$ and localized PCa (PT) of the indicated patient datasets. One tail Student $t$-test. ${ }^{*} p<0.05$;

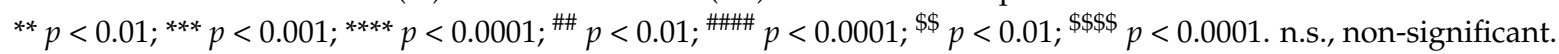


EZH2 expression is positively associated with PCa pathogenesis and progression [49]. We interrogated whether the regulation of $C E R K$ by $E Z H 2$ could be a general phenomenon in this tumor type. To this end, we studied the correlation between CERK and EZH2 mRNA abundance. Interestingly, we observed an inverse correlation between the expression of the two genes in various PCa cohorts (Figure 3F and Figure S4B). We then evaluated whether this regulation could influence the expression of CERK in PCa. Analysis of available PCa datasets confirmed that $E Z H 2$ was predominantly upregulated in localized PCa compared to normal prostate (Figure 3G), and this phenomenon was associated with a robust downregulation of CERK in the same datasets. These results strongly suggest that $\mathrm{AR}$ represses $C E R K$, at least in part, through $\mathrm{EZH} 2$, and that the epigenetic modifier might be a general regulator of CERK expression beyond AR.

We and others have previously shown that the product of CERK, C1P, promotes cancer cell aggressiveness in other cellular systems [50]. Therefore, we tested the influence of $\mathrm{C} 1 \mathrm{P}$ in prostate cancer cell function. First, we generated spheroids of LNCaP cells. These spheroids were embedded in collagen, challenged with vehicle or C1P $(20 \mu \mathrm{M})$, and the increase in the total area of the structure was evaluated 7 days later. Interestingly, C1P treatment did not influence two-dimensional cell growth but increased spheroid diameter (Figure $4 \mathrm{~A}, \mathrm{~B})$. Second, C1P treatment $(20 \mu \mathrm{M})$ slightly increased the migration of LNCaP cells in wound healing assays (Figure $4 \mathrm{C}$ ). Third, we performed transwell migration assays in a migratory prostate cancer cell line, namely PC3. C1P elicited a time-dependent increase in cell migration, over a monitored period of $72 \mathrm{~h}$ (Figure $4 \mathrm{D}$ ). As a control of this assay, we tested the effect of the non-phosphorylated counterpart $\left(\mathrm{C}_{2}\right.$-Ceramide, $\left.\mathrm{C} 2 \mathrm{C}\right)$ on PC3 cells. As reported [50] we corroborated the growth-suppressive activity of this sphingolipid (Figure S5A,B).

To further ascertain the role of CERK in PCa cell biology we set up genetic manipulation tools to perturb CERK expression. We chose to silence CERK in PCa cells with high and low expression of this gene, PC3 and LNCaP, respectively. We generated two independent inducible lentiviral shRNA sequences that efficiently reduced CERK mRNA abundance (Figure $\mathrm{S5C}$ ). In agreement with our $\mathrm{C} 1 \mathrm{P}$ supplementation results, CERK silencing reduced aggressive properties without affecting cell proliferation in PC 3 cells, but had no functional consequences in CERK low expressing cells, LNCaP (Figure S5D,E).

These results reinforce the notion that ceramide phosphorylation by CERK could have a biological impact on prostate cancer cells. 
A

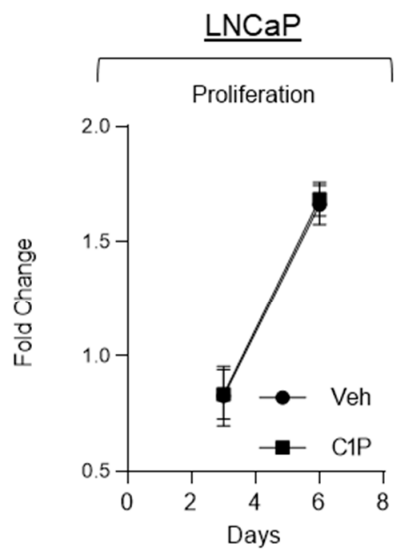

C

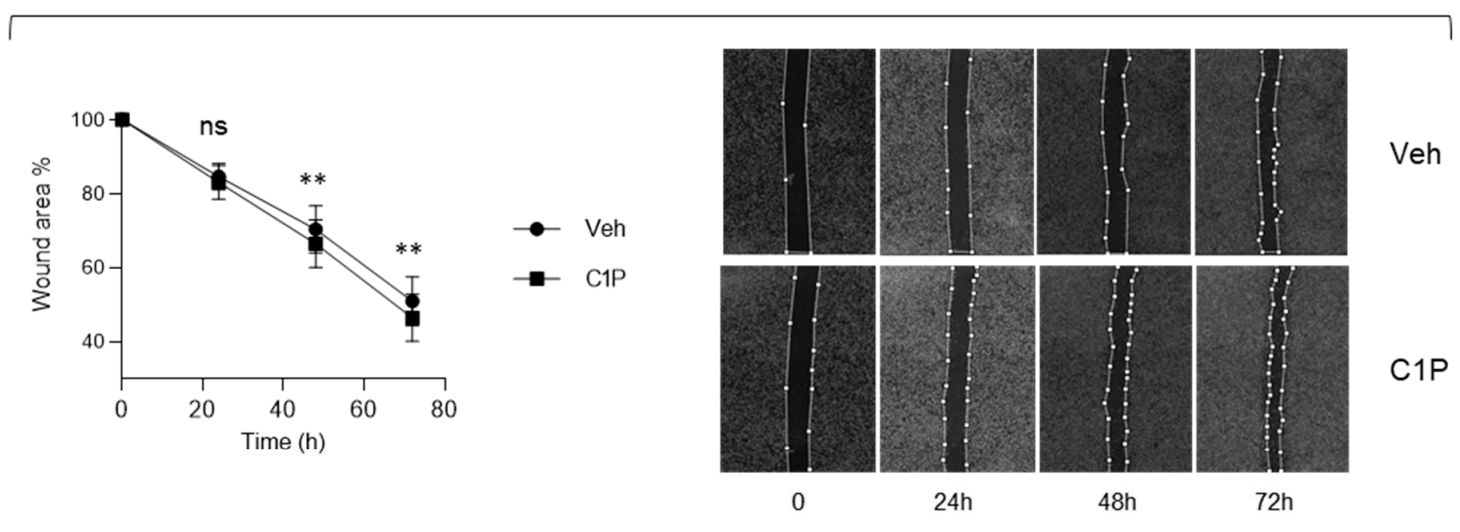

B

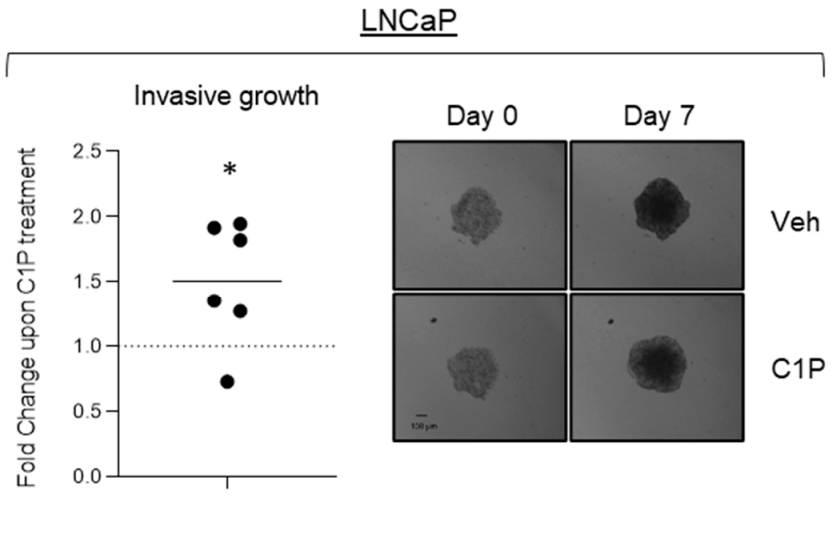

$\underline{\mathrm{LNCaP}}$

D

PC3

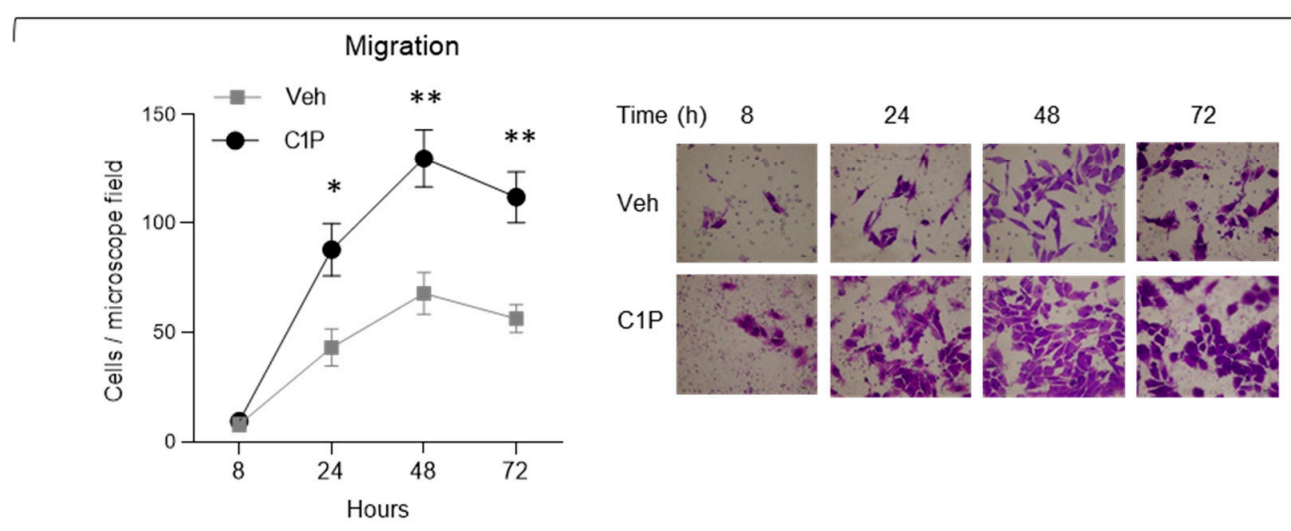

Figure 4. C1P promotes prostate cancer cell migration and invasive growth. (A) Proliferation upon treatment with $20 \mu \mathrm{M}$ ceramide-1-phosphate (C1P) in LNCaP cells ( $n=3$ independent experiments). Paired $t$-test. Comparisons made versus vehicles. (B) Quantification of spheroid diameter increase upon treatment with $20 \mu \mathrm{M} \mathrm{C1P}$ in LNCaP cells compared to vehicle (Veh) ( $n=6$ independent experiments), one-sample $t$-test, and representative images of the spheroids at seeding and the end of the experiment. (C) Quantification of wound healing migration assay upon treatment with $20 \mu \mathrm{M} \mathrm{C1P}$ in LNCaP cells compared to vehicle (Veh) ( $n=3$ independent experiments, paired $t$-test), and representative images of the wound area at seeding and at the different measured time points. (D) Quantification and representative images of cell migration upon treatment with $20 \mu \mathrm{M} \mathrm{C1P}$ in PC3 cells compared to vehicle (Veh) ( $n=4$ independent experiments). Unpaired $t$-test. All comparisons are two-tailed. ${ }^{*} p<0.05 ;{ }^{* *} p<0.01$. 


\section{Discussion}

The signaling cascade regulated by AR is essential for the function of prostate cells $[6,7,9]$. The studies of AR transcriptional regulation were limited to a few AR-target genes but thanks to the advances in high-throughput genomic technologies, now we know that this nuclear receptor regulates the expression of more than 1500 genes [15,47]. Androgen-bound $\mathrm{AR}$ is primarily known as a transcription activator but additional evidence shows that it can also repress gene expression $[16,17]$. Only a handful of genes have been molecularly characterized as directly repressed by AR $[17,45,51]$. In this context, our results provide detailed molecular regulation of a gene repressed by $\mathrm{AR}$, with validations that encompass human specimens, murine models, and cellular systems. In turn, our work, together with previous studies by other groups, encourages a more extensive analysis of the molecular determinants of AR-elicited transcriptional activation vs. repression.

Lipid uptake and metabolism is under the control of androgen signaling [20,52-57]. In fact, elevated lipid biosynthesis has been postulated to promote the development of castration-resistant PCa [52,54], and inhibition of fatty acid synthase has been proposed as a therapeutic strategy to target this pathological state [53]. Despite the vast knowledge around lipid metabolism regulation by androgens, the information around the role and relevance of these hormones in the control of sphingolipid metabolism is limited. Sphingolipid metabolism produces metabolites that influence multiple biological processes [26,58,59]. Phosphorylation of ceramide species illustrates the dichotomy of sphingolipids in the regulation of cell survival and motility vis a vis cell death $[50,60]$. In this regard, CERK activity is predicted to support cell viability, with an increase in the pool of phosphorylated ceramide. Our results corroborate that $\mathrm{C} 1 \mathrm{P}$ can promote prostate cancer cell aggressiveness. Since AR represses CERK, the functional outcome of this regulation would be a decrease in C1P. Conversely, our results suggest that loss of AR signaling derepresses CERK and leads to the elevation of $\mathrm{C} 1 \mathrm{P}$, which could counteract the therapeutic effect of $\mathrm{AR}$ antagonists and uncover a mechanism for the development of castration-resistant PCa. Moreover, this increase in CERK levels could represent an unprecedented target to curb prostate cancer aggressiveness, as demonstrated in AR-negative PC3 cells. The specific pathophysiological context in which this regulation be therapeutically exploited remains to be defined.

EZH2 is an epigenetic modifier that is overexpressed in multiple cancer types [61]. In $\mathrm{PCa}$, this gene is associated with disease progression and metastasis [49], and the crosstalk between AR and this factor has been previously reported [45,62-64]. Interestingly, we report that EZH2 represses CERK. EZH2 inhibitor GSK126 elicited robust activation of $C E R K$ expression, and combination with AR agonists and antagonists interfered with the repressive activity of androgen signaling on this gene. Moreover, EZH2 interacted with the androgen receptor site in CERK regulatory region. Our analysis of CERK and EZH2 gene expression in PCa datasets suggests that the action of the epigenetic modifier on CERK might be operational beyond the context of AR. In turn, our results open a new area for the study of Polycomb group proteins in the control of sphingolipid metabolism.

\section{Materials and Methods}

\subsection{Cell Culture}

Human prostate cancer cell lines PC3, DU145, LNCaP and the benign prostate hyperplasia cell line BPH1 were purchased from Leibniz Institut DSMZ (Deutsche Sammlung von Mikroorganismen und Zellkulturen $\mathrm{GmbH}$ ), who provided authentication certificate. Human prostate cancer cell lines 22RV1 and VCaP were purchased from American Type Culture Collection (ATCC). Human prostate cancer cell line C4-2, and human prostatic epithelial cell lines PWR1E and RWPE1 were generously provided by the laboratory of Dr. Pier Paolo Pandolfi. Cell lines were periodically subjected to microsatellite-based identity validation. The cell lines used in this study were not found in the database of commonly misidentified cell lines maintained by ICLAC and NCBI Biosample. All cell lines were routinely monitored for mycoplasma contamination. DU145, PC3, and VCaP cell lines were maintained in Dulbecco's Modified Eagle Medium (DMEM) while LNCaP, C4-2, and 22RV1 
cell lines were maintained in regular Roswell Park Memorial Institute (RPMI) medium without any supplement except for complete $10 \%(v / v)$ fetal bovine serum (FBS, Gibco) and $1 \%(v / v)$ penicillin-streptomycin (Gibco). PWR1E and RWPE1 cell lines were maintained in Keratinocyte Serum-Free Medium (K-SFM; Gibco) supplemented with $0.05 \mathrm{mg} / \mathrm{mL}$ bovine pituitary extract (BPE; Gibco) and $5 \mathrm{ng} / \mathrm{mL}$ epidermal growth factor (EGF; Gibco). BPH1 was maintained in RPMI medium supplemented with 20\% FBS, $20 \mathrm{ng} / \mathrm{mL}$ DHT, $5 \mathrm{ug} / \mathrm{mL}$ transferrin, $5 \mu \mathrm{g} / \mathrm{mL}$ insulin, and $5 \mathrm{ng} / \mathrm{mL}$ sodium selenite (all supplements from Sigma-Aldrich St. Louis, MO, USA).

\subsection{Generation of Stable Cell Lines}

293FT cells were used for lentiviral production. Lentiviral vectors expressing validated shRNAs against human CERK from the Mission shRNA Library were subcloned in a Plko Tet on inducible system (following the strategy provided by Dr. Dmitri Wiederschain [65], Addgene plasmid \# 21915). Cells were transfected with lentiviral vectors following standard procedures, and viral supernatant was used to infect cells. The selection was done using puromycin $(2 \mu \mathrm{g} / \mathrm{mL})$ for $48 \mathrm{~h}$. As a control, a lentivirus with scrambled shRNA (shC) was used. (Short hairpins sequences: sh88: CCGGGCCACGATGGATCGCTGGTTTCTCGAGAAACCAGCGATCCATCGTG GCTTTTTG, sh89: CCGGCGGCTTAAACTTTGATCTGTACTCGAGTACAGA TCAAAGTTTAAGC CGTTTTTTG, shC: CCGGCAACAAGATGAAGAGCACCAACTCGAGTTGGTGCTCTTCATCTTG TTG.

\subsection{Reagents}

DHT (4,5 $\alpha$-Dihydrotestosterone) was purchased from Sigma-Aldrich (St. Louis, MO, USA; A8380) and dissolved in ethanol at $10 \mu \mathrm{M}$ to be used at a final concentration of $10 \mathrm{nM}$. MDV3100 (enzalutamide), from Santa Cruz Biotechnology (Dallas, TX, USA; sc-364354),

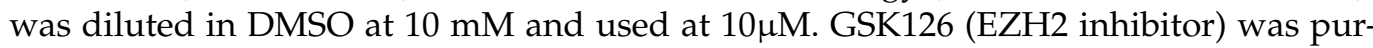
chased from MedChemExpress (Monmouth Junction, NJ, USA; HY-13470), dissolved in DMSO, and used in a range of concentrations for $24 \mathrm{~h}$. C2 Ceramide (N-acetoyl-Derythro-sphingosine) was purchased from Avanti Polar Lipids (Alabaster, AL, US; 860502), dissolved in DMSO, and used at a final concentration of $20 \mu \mathrm{M}$. Doxycycline Hyclate (Dox, used at a final concentration of $0.25 \mu \mathrm{g} / \mathrm{mL}$ ) and C16 Ceramide 1-phosphate (C1P, 860533P) were purchased from Sigma Aldrich (St. Louis, MO, US). An aqueous dispersion (in the form of liposomes) was prepared by sonicating C1P (1 mg) in sterile nanopure water $(600 \mu \mathrm{L})$ on ice using a probe sonicator for six cycles of $8 \mathrm{~s}$ on and $5 \mathrm{~s}$ off until a clear dispersion was obtained. C1P concentration in the stock solution was $2.6 \mathrm{mM}$ and a final concentration of $20 \mu \mathrm{M}$ was used for all cellular assays. This procedure is considered preferable to $\mathrm{C} 1 \mathrm{P}$ dispersions in organic solvents because lipid droplet formation is minimized and exposure of cells to alcohols or dodecane is avoided.

\subsection{Animals}

Prostate epithelium-specific deletion Pten knockout (C57/BL6/129sv; Pb-Cre4; Pten lox/lox) model was kindly provided by Dr. Pandolfi. All mouse experiments were carried out following the ethical guidelines established by the Biosafety and Welfare Committee at CIC bioGUNE (Spanish acronym for center for cooperative research in Biosciences). The procedures employed were carried out following the recommendations from AAALAC (Association for Assessment and Accreditation of Laboratory Animal Care). Orchiectomy was performed in 4 months Pten $^{p c+/+}$ mice and 6 months Pten ${ }^{p c-/-}$ mice, and 6 days later prostate lobules were collected. Mice were fasted for $6 \mathrm{~h}$ prior to tissue harvest to prevent metabolic alterations due to immediate food intake.

\section{5. qRTPCR}

RNA was extracted using a NucleoSpin ${ }^{\circledR}$ RNA isolation kit (Macherey-Nagel, Dueren, Germany; 740955.240C). For animal tissues, a Trizol-based implementation of the NucleoSpin ${ }^{\circledR}$ RNA isolation kit protocol (Provided above) was used as referenced [66]. For all cases, 
$1 \mu \mathrm{g}$ of total RNA was used for cDNA synthesis using Maxima ${ }^{\mathrm{TM}} \mathrm{H}$ Minus cDNA Synthesis Master Mix (ThermoFisher, Waltham, MA, US; M1682). Quantitative Real-Time PCR (qRTPCR) was performed as previously described [67]. Universal Probe Library (Roche, Basel, Switzerland) primers and probes employed (Roche; ThermoFisher) are detailed in Table S1. All qRTPCR data presented was normalized using GAPDH/Gapdh (ThermoFisher; Hs02758991_g1, Mm99999915_g1).

\subsection{Sphingolipid Metabolic Analysis}

LNCaP cells were treated with vehicle or MDV for $24 \mathrm{~h}$ and two million cells per condition were washed, pelleted and sent for analysis. Internal standards were purchased from Avanti Polar Lipids (Alabaster, AL, USA) and were added to samples in $10 \mu \mathrm{L}$ ethanol:methanol:water (7:2:1) as a cocktail of 250 pmol each. Standards for sphingoid bases and sphingoid base 1-phosphates were 17-carbon chain length analogs: C17-sphingosine, (2S,3R,4E)-2-aminoheptadec-4-ene-1,3-diol (d17:1-So); C17-sphinganine, (2S,3R)-2aminoheptadecane-1,3-diol (d17:0-Sa); C17-sphingosine 1-phosphate, heptadecasphing-4enine-1-phosphate (d17:1-So1P); and C17-sphinganine 1-phosphate, heptadecasphinganine1-phosphate (d17:0-Sa1P). Standards for N-acyl sphingolipids were C12-fatty acid analogs: C12-Cer, $\mathrm{N}$-(dodecanoyl)-sphing-4-enine (d18:1/C12:0); C12-Cer 1-phosphate, N-(dodecanoyl)sphing-4-enine-1-phosphate (d18:1/C12:0-Cer1P); C12-sphingomyelin, N-(dodecanoyl)sphing-4-enine-1-phosphocholine (d18:1/C12:0-SM); and C12-glucosylceramide, N(dodecanoyl)-1- $\beta$-glucosyl-sphing-4-eine.

Sample homogenates were collected into $13 \times 100 \mathrm{~mm}$ borosilicate tubes with a Teflon-lined cap (catalog \#60827-453, VWR, West Chester, PA, USA). Then $2 \mathrm{~mL}$ of $\mathrm{CH} 3 \mathrm{OH}$ and $1 \mathrm{~mL}$ of $\mathrm{CHCl} 3$ were added along with the internal standard cocktail ( $250 \mathrm{pmol}$ of each species dissolved in a final total volume of $10 \mu \mathrm{L}$ of ethanol:methanol:water 7:2:1). The contents were dispersed using an ultra sonicator at room temperature for $30 \mathrm{~s}$. This single-phase mixture was incubated at $48{ }^{\circ} \mathrm{C}$ overnight. After cooling, $150 \mu \mathrm{L}$ of $1 \mathrm{M}$ $\mathrm{KOH}$ in $\mathrm{CH} 3 \mathrm{OH}$ was added and, after brief sonication, incubated in a shaking water bath for $2 \mathrm{~h}$ at $37^{\circ} \mathrm{C}$ to cleave potentially interfering glycerolipids. The extract was brought to neutral $\mathrm{pH}$ with $12 \mu \mathrm{L}$ of glacial acetic acid, then the extract was centrifuged using a table-top centrifuge, and the supernatant was removed by a Pasteur pipette and transferred to a new tube. The extract was reduced to dryness using a Speed Vac. The dried residue was reconstituted in $0.5 \mathrm{~mL}$ of the starting mobile phase solvent for LC-MS/MS analysis, sonicated for ca $15 \mathrm{~s}$, then centrifuged for $5 \mathrm{~min}$ in a tabletop centrifuge before the transfer of the clear supernatant to the autoinjector vial for analysis.

For LC-MS/MS analyses, a Shimadzu Nexera LC-30 AD binary pump system coupled to a SIL-30AC autoinjector and DGU20A5R degasser coupled to an AB Sciex 5500 quadrupole/linear ion trap (QTrap) (SCIEX, Framingham, MA, USA) operating in a triple quadrupole mode was used. Q1 and Q3 were set to pass molecularly distinctive precursor and product ions (or a scan across multiple $m / z$ in $Q 1$ or Q3), using N2 to collisionally induce dissociations in $\mathrm{Q} 2$ (which was offset from $\mathrm{Q} 1$ by $30-120 \mathrm{eV}$ ); the ion source temperature set to $500{ }^{\circ} \mathrm{C}$.

The compounds were separated by reverse-phase LC using a Supelco 2.1 (i.d.) $\times 50 \mathrm{~mm}$ Ascentis Express C18 column (Sigma, St. Louis, MO, USA) and a binary solvent system at a flow rate of $0.5 \mathrm{~mL} / \mathrm{min}$ with a column oven set to $35^{\circ} \mathrm{C}$. Prior to injection of the sample, the column was equilibrated for $0.5 \mathrm{~min}$ with a solvent mixture of $95 \%$ Moble phase A1 $(\mathrm{CH} 3 \mathrm{OH} / \mathrm{H} 2 \mathrm{O} / \mathrm{HCOOH}, 58 / 41 / 1, v / v / v$, with $5 \mathrm{mM}$ ammonium formate) and $5 \%$ Mobile phase $\mathrm{B} 1(\mathrm{CH} 3 \mathrm{OH} / \mathrm{HCOOH}, 99 / 1, v / v$, with $5 \mathrm{mM}$ ammonium formate), and after sample injection (typically $40 \mu \mathrm{L}$ ), the A1/B1 ratio was maintained at $95 / 5$ for $2.25 \mathrm{~min}$, followed by a linear gradient to $100 \%$ B1 over $1.5 \mathrm{~min}$, which was held at $100 \%$ B1 for $5.5 \mathrm{~min}$, followed by a 0.5 min gradient return to $95 / 5 \mathrm{~A} 1 / \mathrm{B} 1$. The column was re-equilibrated with 95:5 A1/B1 for 0.5 min before the next run. 


\subsection{ChIP}

Chromatin Immunoprecipitation (ChIP) was performed using the SimpleChIP ${ }^{\circledR}$ Enzymatic Chromatin IP Kit (Cell Signalling Technology, Inc, Danvers, MA, USA; 9003) following the manufacturer's instructions. Three million LNCaP cells were seeded in $150 \mathrm{~mm}$ dishes. Three days later each dish containing $20 \mathrm{~mL}$ medium was treated with vehicle or DHT for $4 \mathrm{~h}$ and then was cross-linked with $540 \mu \mathrm{L} 35 \%$ formaldehyde for $10 \mathrm{~min}$ at room temperature. Glycine was added to dishes, and cells were incubated for $5 \mathrm{~min}$ at room temperature. Cells were then washed twice with ice-cold PBS and scraped into PBS + PIC (Protease Inhibitor Cocktail). Pelleted cells were lysed and nuclei were harvested. Nuclear lysates were digested with micrococcal nuclease for $20 \mathrm{~min}$ at $37^{\circ} \mathrm{C}$ and then sonicated in $500 \mu \mathrm{L}$ aliquots on ice for 6 pulses of $20 \mathrm{~s}$ (with $20 \mathrm{~s}$ gaps) using a Branson sonicator. Lysates were clarified at $10,000 \times g$ for $10 \mathrm{~min}$ at $4{ }^{\circ} \mathrm{C}$, and chromatin was stored at $-80^{\circ} \mathrm{C}$. Androgen Receptor polyclonal rabbit antibody (Santa Cruz Biotechnology, Dallas, TX, USA; D2C9), EZH2 monoclonal rabbit antibody (Cell Signaling Technology, Danvers, MA, USA; N-20), and IgG antibody (Cell Signalling Technology, Inc, Danvers, MA, USA; 2729), were incubated overnight at $4{ }^{\circ} \mathrm{C}$ with rotation and protein $\mathrm{G}$ magnetic beads were incubated $2 \mathrm{~h}$ at $4{ }^{\circ} \mathrm{C}$. Washes and elution of chromatin were performed following the manufacturer's instructions. DNA quantification was carried out using a Viia7 Real-Time PCR System (ThermoFisher, Waltham, MA, USA) with SYBR-Green reagents and primers that amplify Androgen Receptor sites (AR sites) present in CERK sequence as well as KLK3 enhancer region [68] as control (detailed in Table S3).

\subsection{Cellular Assays}

\subsubsection{Cell Growth Analysis}

15,000 PC3 cells or 30,000 LNCaP cells were plated in triplicate in 12-well dishes. Twenty-four hours later, the cells considered day 0 were fixed in formalin $10 \%$. The same procedure was performed on the days indicated in Figure 4A and Figure S5. Cell growth was measured by staining with crystal violet $(0.1 \%$ in $20 \%$ methanol) for $45 \mathrm{~min}$. The precipitate was solubilized in 10\% acetic acid, and the absorbance was measured at $595 \mathrm{~nm}$.

\subsubsection{Invasive Growth}

40,000 cells were resuspended in 1ml RPMI with $6 \%$ methylcellulose (Sigma-Aldrich St. Louis, MO, USA; M0387). Drops ( $25 \mu \mathrm{L})$ were pipetted on the cover of a $100 \mathrm{~mm}$ culture plate. The inverted plates were incubated at $37^{\circ} \mathrm{C}$ and $5 \% \mathrm{CO}_{2}$ for $72 \mathrm{~h}$. Once formed, spheroids were collected, resuspended in collagen I solution $(1.7 \mathrm{mg} / \mathrm{mL}$ in DMEM) with or without $20 \mu \mathrm{M} \mathrm{C1P}$, and seeded in a 24-well plate. Day 0 pictures were taken and complete RPMI media was then added on top of the collagen. Spheroids were maintained at $37^{\circ} \mathrm{C}$ and $5 \% \mathrm{CO}_{2}$ for 7 days and pictures were again taken. The area of the spheroids was measured using FiJi software. Relative invasive growth was quantified as area difference on day 7 minus day 0 .

\subsubsection{Wound Healing}

$600,000 \mathrm{LNCaP}$ cells were plated in duplicates in 6-well plates, grown to confluency, and the cell monolayer was wounded with a pipette tip. Photomicrographs of each scratch were obtained at the initial time of wound creation and the same location was photographed every $24 \mathrm{~h}$ until completion of the study. Fiji software was used to quantify the area of the wound remaining. This number was then converted to a percentage of the scratch area remaining at each time point.

\subsubsection{Migration}

24-well plates with $8 \mu \mathrm{m}$ pore size chambers (Corning Costar \#3422) were precoated

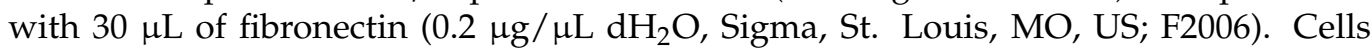
(50,000 in $100 \mu \mathrm{L}$ per insert) were resuspended in a medium supplemented with $0.2 \%$ fatty acid-free bovine serum albumin (BSA) and seeded in duplicates to the upper part of the 
chamber of 24 -well plates. $300 \mu \mathrm{L}$ media with $0.2 \%$ BSA with or without $20 \mu \mathrm{M} \mathrm{C1P}$ was added to the lower wells. After the corresponding incubation time (8 to $72 \mathrm{~h}$ ) at $37{ }^{\circ} \mathrm{C}$ and $5 \% \mathrm{CO}_{2}$, chambers were washed and non-migrated cells were removed with a cotton swab. Filters were fixed with formaldehyde (5\% in PBS) and stained with $0.1 \%$ crystal violet. Cell migration was assessed by counting the number of migrated cells in a Nikon Eclipse 90i microscope equipped with NIS-Elements 3.0 software. Cells were counted in eight randomly selected microscope fields per filter at 20x magnification.

\subsubsection{Anchorage-Independent Growth}

6 well-plates were coated with a lower layer of $0.6 \%$ agar (SeaKem LE agarose, Lonza, Basel, Switzerland) medium mixture ( $3 \mathrm{~mL} /$ well) and stored at $4{ }^{\circ} \mathrm{C}$ for at least $30 \mathrm{~min}$ to let the agar solidify. 5000 PC 3 cells or 15,000 LNCaP cells per well were suspended in a 0.3\% low melting agar (Agarose LM, Pronadisa, Conda, Madrid, Spain) medium mixture and $1 \mathrm{~mL} /$ well were plated in duplicates. Plates were stored at $4{ }^{\circ} \mathrm{C}$ (around $30 \mathrm{~min}$ ) to allow the solidification of the upper layer and then incubated at $37^{\circ} \mathrm{C}$ in a humidified atmosphere of $5 \% \mathrm{CO}_{2}$ for 3-4 weeks, until colony detection. Colonies were then quantified using Fiji software (ImageJ version 1.53c).

\subsection{Bioinformatics Analysis and Statistics}

Correlations and enrichment bioinformatics analysis were performed with Cancertool [28]. No statistical method was used to predetermine sample size. The experiments were not randomized. The investigators were not blinded to allocation during experiments and outcome assessment. $n$ values represent the number of independent experiments performed or the number of individual mice. For each independent in vitro experiment, at least two technical replicates were used and a minimum number of three experiments were performed to ensure adequate statistical power. For in vitro experiments normal distribution was assumed. One sample $t$-test was applied for one component comparisons with control when one of the two groups did not have a variance and paired $t$-test for matched data in each experiment. One-way ANOVA was used for multiple comparisons. For in vivo experiments a non-parametric Mann-Whitney exact test was used. Unless otherwise stated, data analyzed by parametric tests are represented by the mean \pm s.e.m. of pooled experiments and median \pm interquartile range for experiments analyzed by non-parametric tests. Two-tail statistical analysis was applied for experimental design without predicted result and one-tail for validation or hypothesis-driven experiments. The confidence level used for all the statistical analyses was 95\% (alpha value $=0.05$ ). GraphPad Prism 8 software was used for statistical calculations.

\section{Conclusions}

In this study, we demonstrate the potential of computational analysis using publicly available transcriptional datasets to identify novel metabolic targets of AR in prostate cancer. The repressive control of ceramide kinase by this nuclear receptor exemplifies the complex functions of hormone signaling in this disease.

Supplementary Materials: The following are available online at https:/ /www.mdpi.com/article/10 .3390/cancers13174307/s1, Figure S1: Regulation of candidate sphingolipid metabolism enzymes by androgen signaling; Figure S2: Regulation of CERK by androgen signaling in cell lines and patient specimens; Figure S3: LC/MS analysis of phosphorylated and non-phosphorylated ceramides and sphingosine; Figure S4: Regulation of CERK by EZH2; Figure S5: Biological consequences of genetic and pharmacological manipulation of ceramide-1-phosphate levels. Table S1: Androgen receptor signature genes; Table S2: Androgen receptor metabolic correlome; Table S3: Universal Probe Library (Roche) probes/primers and ChIP qPCR primers employed in this study.

Author Contributions: L.C. performed the majority of molecular, cellular, and in vivo analysis, and participated in experimental design and bioinformatics analyses. A.Z.-L. participated in the in vivo analyses. A.R.C. performed bioinformatics analyses and representations. I.A., A.D.-H., C.V., S.F.-R., and A.M.-G. provided support with cellular assays. A.E. and J.C. provided support with wound 
healing assays. V.T. and N.M.-M. provided support with molecular analyses. A.C. and A.G.-M. conceived the study and supervised the execution of the project. A.C. led the project, coordinated the experimental design, and wrote the manuscript. All authors have read and agreed to the published version of the manuscript.

Funding: A.G.-M. is funded by the MINECO (SAF2016-79695-R) and the department of education (IKERTALDE IT1106-16). V.T. is funded by Fundación Vasca de Innovación e Investigación Sanitarias, BIOEF (BIO15/CA/052), the AECC J.P. Bizkaia and the Basque Department of Health (2016111109) and the MINECO RTI2018-097267-B-I00. The work of A. Carracedo is supported by the Basque Department of Industry, Tourism and Trade (Elkartek), the department of education (IKERTALDE IT1106-16) and health (RIS3), the MICINN (PID2019-108787RB-I00 (FEDER/EU); Severo Ochoa Excellence Accreditation SEV-2016-0644; Excellence Networks RED2018-102769-T), the AECC (GCTRA18006CARR), La Caixa Foundation (ID 100010434), under the agreement LCF/PR/HR17/ and the European Research Council (Consolidator Grant 819242). CIBERONC was co-funded with FEDER funds and funded by ISCIII.

Institutional Review Board Statement: The study was conducted according to the guidelines of the Declaration of Helsinki, and the work related to experimental mice was approved by the Institutional Review Board of CIC bioGUNE (protocol code P-CBG-CBBA-0715 and P-CBG-CBBA-0121).

Informed Consent Statement: Not applicable.

Data Availability Statement: The data presented in this study are available in this article (and Supplementary Material). The authors are available for any additional inquiries related to the data and the procedures.

Acknowledgments: We are grateful to the Carracedo lab for valuable input and to the Lipidomics / Metabolomics Core at Virginia Commonwealth University School of Medicine (VCU), with NIH-NCI Cancer Center Support Grant P30 CA016059 to the VCU Massey Cancer Center, and a shared resource grant (S10RR031535) from the National Institutes of Health.

Conflicts of Interest: The authors declare no conflict of interest.

\section{References}

1. Litwack, G. Steroid Hormones Chapter 16. In Human Biochemistry; Litwack, G., Ed.; Academic Press: Boston, MA, USA, 2018; pp. 467-506. [CrossRef]

2. Whirledge, S.; Cidlowski, J.A. Chapter 5-Steroid Hormone Action. In Yen and Jaffe's Reproductive Endocrinology, 8th ed.; Strauss, J.F., Barbieri, R.L., Eds.; Content Repository Only: Philadelphia, PA, USA, 2019; pp. 115-131.e4. [CrossRef]

3. Sever, R.; Glass, C.K. Signaling by nuclear receptors. Cold Spring Harb. Perspect. Biol. 2013, 5, a016709. [CrossRef]

4. Davey, R.A.; Grossmann, M. Androgen Receptor Structure, Function and Biology: From Bench to Bedside. Clin. Biochem. Rev. 2016, 37, 3-15.

5. Culig, Z.; Santer, F.R. Androgen receptor signaling in prostate cancer. Cancer Metastasis Rev. 2014, 33, 413-427. [CrossRef]

6. Dai, C.; Heemers, H.; Sharifi, N. Androgen Signaling in Prostate Cancer. Cold Spring Harb. Perspect. Med. 2017, 7, a030452. [CrossRef] [PubMed]

7. Crawford, E.D.; Heidenreich, A.; Lawrentschuk, N.; Tombal, B.; Pompeo, A.C.L.; Mendoza-Valdes, A.; Miller, K.; Debruyne, F.M.J.; Klotz, L. Androgen-targeted therapy in men with prostate cancer: Evolving practice and future considerations. Prostate Cancer Prostatic Dis. 2019, 22, 24-38. [CrossRef] [PubMed]

8. Heemers, H.V. Targeting Androgen Receptor Action for Prostate Cancer Treatment: Does the Post-Receptor Level Provide Novel Opportunities? Int. J. Biol. Sci. 2014, 10, 576-587. [CrossRef] [PubMed]

9. Saranyutanon, S.; Srivastava, S.K.; Pai, S.; Singh, S.; Singh, A.P. Therapies Targeted to Androgen Receptor Signaling Axis in Prostate Cancer: Progress, Challenges, and Hope. Cancers 2019, 12, 51. [CrossRef]

10. Ku, S.Y.; Gleave, M.E.; Beltran, H. Towards precision oncology in advanced prostate cancer. Nat. Rev. Urol. 2019, 16, 645-654. [CrossRef]

11. Teo, M.Y.; Rathkopf, D.E.; Kantoff, P. Treatment of Advanced Prostate Cancer. Annu. Rev. Med. 2019, 70, 479-499. [CrossRef]

12. Mansinho, A.; Macedo, D.; Fernandes, I.; Costa, L. Castration-Resistant Prostate Cancer: Mechanisms, Targets and Treatment. Adv. Exp. Med. Biol. 2018, 1096, 117-133. [CrossRef]

13. Sharma, N.L.; Massie, C.E.; Ramos-Montoya, A.; Zecchini, V.; Scott, H.E.; Lamb, A.D.; MacArthur, S.; Stark, R.; Warren, A.Y.; Mills, I.G.; et al. The Androgen Receptor Induces a Distinct Transcriptional Program in Castration-Resistant Prostate Cancer in Man. Cancer Cell 2013, 23, 35-47. [CrossRef]

14. Olsen, J.R.; Azeem, W.; Hellem, M.R.; Marvyin, K.; Hua, Y.; Qu, Y.; Li, L.; Lin, B.; Ke, X.I.S.; Øyan, A.M.; et al. Context dependent regulatory patterns of the androgen receptor and androgen receptor target genes. BMC Cancer 2016, 16, 377. [CrossRef] [PubMed]

15. Jin, H.J.; Kim, J.; Yu, J. Androgen receptor genomic regulation. Transl. Androl. Urol. 2013, 2, 157-177. [CrossRef] [PubMed] 
16. Gritsina, G.; Gao, W.Q.; Yu, J. Transcriptional repression by androgen receptor: Roles in castration-resistant prostate cancer. Asian J. Androl. 2019, 21, 215-223. [CrossRef]

17. Nassar, Z.D.; Mah, C.Y.; Dehairs, J.; Burvenich, I.J.; Irani, S.; Centenera, M.M.; Helm, M.; Shrestha, R.K.; Moldovan, M.; Don, A.S.; et al. Human DECR1 is an androgen-repressed survival factor that regulates PUFA oxidation to protect prostate tumor cells from ferroptosis. Elife 2020, 9, e54166. [CrossRef]

18. Clocchiatti, A.; Ghosh, S.; Procopio, M.G.; Mazzeo, L.; Bordignon, P.; Ostano, P.; Goruppi, S.; Bottoni, G.; Katarkar, A.; Levesque, M.; et al. Androgen receptor functions as transcriptional repressor of cancer-associated fibroblast activation. J. Clin. Investig. 2018, 128, 5531-5548. [CrossRef]

19. Boulkroun, S.; Le Moellic, C.; Blot-Chabaud, M.; Farman, N.; Courtois-Coutry, N. Expression of androgen receptor and androgen regulation of NDRG2 in the rat renal collecting duct. Pflügers Arch. 2005, 451, 388-394. [CrossRef]

20. Mah, C.Y.; Nassar, Z.D.; Swinnen, J.V.; Butler, L.M. Lipogenic effects of androgen signaling in normal and malignant prostate. Asian J. Urol. 2020, 7, 258-270. [CrossRef]

21. Putluri, N.; Shojaie, A.; Vasu, V.T.; Nalluri, S.; Vareed, S.K.; Putluri, V.; Vivekanandan-Giri, A.; Byun, J.; Pennathur, S.; Sana, T.R.; et al. Metabolomic profiling reveals a role for androgen in activating amino acid metabolism and methylation in prostate cancer cells. PLoS ONE 2011, 6, e21417. [CrossRef] [PubMed]

22. Szabó, Z.; Hämäläinen, J.; Loikkanen, I.; Moilanen, A.M.; Hirvikoski, P.; Väisänen, T.; Paavonen, T.K.; Vaarala, M.H. Sorbitol dehydrogenase expression is regulated by androgens in the human prostate. Oncol. Rep. 2010, 23, 1233-1239. [CrossRef] [PubMed]

23. Butler, L.M.; Centenera, M.M.; Swinnen, J.V. Androgen control of lipid metabolism in prostate cancer: Novel insights and future applications. Endocr. Relat. Cancer 2016, 23, R219-R227. [CrossRef]

24. Dang, Q.; Chen, Y.A.; Hsieh, J.T. The dysfunctional lipids in prostate cancer. Am. J. Clin. Exp. Urol. 2019, 7, $273-280$.

25. Gangoiti, P.; Camacho, L.; Arana, L.; Ouro, A.; Granado, M.H.; Brizuela, L.; Casas, J.; Fabrias, G.; Abad, J.L.; Delgado, A.; et al. Control of metabolism and signaling of simple bioactive sphingolipids: Implications in disease. Prog. Lipid. Res. 2010, 49, 316-334. [CrossRef] [PubMed]

26. Hannun, Y.A.; Obeid, L.M. Sphingolipids and their metabolism in physiology and disease. Nat. Rev. Mol. Cell Biol. 2018, 19, 175-191. [CrossRef]

27. Massie, C.E.; Lynch, A.; Ramos-Montoya, A.; Boren, J.; Stark, R.; Fazli, L.; Warren, A.; Scott, H.; Madhu, B.; Sharma, N.; et al. The androgen receptor fuels prostate cancer by regulating central metabolism and biosynthesis. EMBO J. 2011, 30, $2719-2733$. [CrossRef] [PubMed]

28. Cortazar, A.R.; Torrano, V.; Martin-Martin, N.; Caro-Maldonado, A.; Camacho, L.; Hermanova, I.; Guruceaga, E.; Lorenzo-Martin, L.F.; Caloto, R.; Gomis, R.R.; et al. CANCERTOOL: A Visualization and Representation Interface to Exploit Cancer Datasets. Cancer Res. 2018, 78, 6320-6328. [CrossRef]

29. Thorek, D.L.; Evans, M.J.; Carlsson, S.V.; Ulmert, D.; Lilja, H. Prostate-specific kallikrein-related peptidases and their relation to prostate cancer biology and detection. Established relevance and emerging roles. Thromb. Haemost. 2013, 110, 484-492. [CrossRef]

30. Possemato, R.; Marks, K.M.; Shaul, Y.D.; Pacold, M.E.; Kim, D.; Birsoy, K.; Sethumadhavan, S.; Woo, H.K.; Jang, H.G.; Jha, A.K.; et al. Functional genomics reveal that the serine synthesis pathway is essential in breast cancer. Nature 2011, 476, 346-350. [CrossRef] [PubMed]

31. Torrano, V.; Valcarcel-Jimenez, L.; Cortazar, A.R.; Liu, X.; Urosevic, J.; Castillo-Martin, M.; Fernandez-Ruiz, S.; Morciano, G.; Caro-Maldonado, A.; Guiu, M.; et al. The metabolic co-regulator PGC1alpha suppresses prostate cancer metastasis. Nat. Cell Biol. 2016, 18, 645-656. [CrossRef] [PubMed]

32. Mouchiroud, L.; Eichner, L.J.; Shaw, R.J.; Auwerx, J. Transcriptional coregulators: Fine-tuning metabolism. Cell Metab. 2014, 20, 26-40. [CrossRef] [PubMed]

33. Glinsky, G.V.; Glinskii, A.B.; Stephenson, A.J.; Hoffman, R.M.; Gerald, W.L. Gene expression profiling predicts clinical outcome of prostate cancer. J. Clin. Investig. 2004, 113, 913-923. [CrossRef]

34. Grasso, C.S.; Wu, Y.M.; Robinson, D.R.; Cao, X.; Dhanasekaran, S.M.; Khan, A.P.; Quist, M.J.; Jing, X.; Lonigro, R.J.; Brenner, J.C.; et al. The mutational landscape of lethal castration-resistant prostate cancer. Nature 2012, 487, 239-243. [CrossRef] [PubMed]

35. Lapointe, J.; Li, C.; Higgins, J.P.; van de Rijn, M.; Bair, E.; Montgomery, K.; Ferrari, M.; Egevad, L.; Rayford, W.; Bergerheim, U.; et al. Gene expression profiling identifies clinically relevant subtypes of prostate cancer. Proc. Natl. Acad. Sci. USA 2004, 101, 811-816. [CrossRef]

36. Taylor, B.S.; Schultz, N.; Hieronymus, H.; Gopalan, A.; Xiao, Y.; Carver, B.S.; Arora, V.K.; Kaushik, P.; Cerami, E.; Reva, B.; et al. Integrative genomic profiling of human prostate cancer. Cancer Cell 2010, 18, 11-22. [CrossRef] [PubMed]

37. Tomlins, S.A.; Mehra, R.; Rhodes, D.R.; Cao, X.; Wang, L.; Dhanasekaran, S.M.; Kalyana-Sundaram, S.; Wei, J.T.; Rubin, M.A.; Pienta, K.J.; et al. Integrative molecular concept modeling of prostate cancer progression. Nat. Genet. 2007, 39, 41-51. [CrossRef]

38. Varambally, S.; Yu, J.; Laxman, B.; Rhodes, D.R.; Mehra, R.; Tomlins, S.A.; Shah, R.B.; Chandran, U.; Monzon, F.A.; Becich, M.J.; et al. Integrative genomic and proteomic analysis of prostate cancer reveals signatures of metastatic progression. Cancer Cell 2005, 8, 393-406. [CrossRef]

39. The Cancer Genome Atlas Research Network. The Molecular Taxonomy of Primary Prostate Cancer. Cell 2015, 163, 1011-1025. [CrossRef] [PubMed] 
40. Fraser, M.; Sabelnykova, V.Y.; Yamaguchi, T.N.; Heisler, L.E.; Livingstone, J.; Huang, V.; Shiah, Y.-J.; Yousif, F.; Lin, X.; Masella, A.P.; et al. Genomic hallmarks of localized, non-indolent prostate cancer. Nature 2017, 541, 359-364. [CrossRef] [PubMed]

41. Coss, C.C.; Bauler, M.; Narayanan, R.; Miller, D.D.; Dalton, J.T. Alanine aminotransferase regulation by androgens in non-hepatic tissues. Pharm. Res. 2012, 29, 1046-1056. [CrossRef]

42. Tomlins, S.A.; Laxman, B.; Dhanasekaran, S.M.; Helgeson, B.E.; Cao, X.; Morris, D.S.; Menon, A.; Jing, X.; Cao, Q.; Han, B.; et al. Distinct classes of chromosomal rearrangements create oncogenic ETS gene fusions in prostate cancer. Nature 2007, 448, 595-599. [CrossRef] [PubMed]

43. Merscher, S.; Fornoni, A. Podocyte pathology and nephropathy-sphingolipids in glomerular diseases. Front. Endocrinol. 2014, 5, 127. [CrossRef] [PubMed]

44. Tran, C.; Ouk, S.; Clegg, N.J.; Chen, Y.; Watson, P.A.; Arora, V.; Wongvipat, J.; Smith-Jones, P.M.; Yoo, D.; Kwon, A.; et al. Development of a second-generation antiandrogen for treatment of advanced prostate cancer. Science 2009, 324, 787-790. [CrossRef] [PubMed]

45. Wu, L.; Runkle, C.; Jin, H.J.; Yu, J.; Li, J.; Yang, X.; Kuzel, T.; Lee, C.; Yu, J. CCN3/NOV gene expression in human prostate cancer is directly suppressed by the androgen receptor. Oncogene 2014, 33, 504-513. [CrossRef] [PubMed]

46. Grosse, A.; Bartsch, S.; Baniahmad, A. Androgen receptor-mediated gene repression. Mol. Cell Endocrinol. 2012, 352, 46-56. [CrossRef]

47. Wilson, S.; Qi, J.; Filipp, F.V. Refinement of the androgen response element based on ChIP-Seq in androgen-insensitive and androgen-responsive prostate cancer cell lines. Sci. Rep. 2016, 6, 32611. [CrossRef] [PubMed]

48. Zhang, Y.; Zheng, D.; Zhou, T.; Song, H.; Hulsurkar, M.; Su, N.; Liu, Y.; Wang, Z.; Shao, L.; Ittmann, M.; et al. Androgen deprivation promotes neuroendocrine differentiation and angiogenesis through CREB-EZH2-TSP1 pathway in prostate cancers. Nat. Commun. 2018, 9, 4080. [CrossRef]

49. Varambally, S.; Dhanasekaran, S.M.; Zhou, M.; Barrette, T.R.; Kumar-Sinha, C.; Sanda, M.G.; Ghosh, D.; Pienta, K.J.; Sewalt, R.G.; Otte, A.P.; et al. The polycomb group protein EZH2 is involved in progression of prostate cancer. Nature 2002, 419, 624-629. [CrossRef]

50. Gomez-Munoz, A. The Role of Ceramide 1-Phosphate in Tumor Cell Survival and Dissemination. Adv. Cancer Res. 2018, 140, 217-234. [CrossRef]

51. Bishop, J.L.; Thaper, D.; Vahid, S.; Davies, A.; Ketola, K.; Kuruma, H.; Jama, R.; Nip, K.M.; Angeles, A.; Johnson, F.; et al. The Master Neural Transcription Factor BRN2 Is an Androgen Receptor-Suppressed Driver of Neuroendocrine Differentiation in Prostate Cancer. Cancer Discov. 2017, 7, 54-71. [CrossRef]

52. Tousignant, K.D.; Rockstroh, A.; Taherian Fard, A.; Lehman, M.L.; Wang, C.; McPherson, S.J.; Philp, L.K.; Bartonicek, N.; Dinger, M.E.; Nelson, C.C.; et al. Lipid Uptake Is an Androgen-Enhanced Lipid Supply Pathway Associated with Prostate Cancer Disease Progression and Bone Metastasis. Mol. Cancer Res. 2019, 17, 1166-1179. [CrossRef]

53. Zadra, G.; Ribeiro, C.F.; Chetta, P.; Ho, Y.; Cacciatore, S.; Gao, X.; Syamala, S.; Bango, C.; Photopoulos, C.; Huang, Y.; et al. Inhibition of de novo lipogenesis targets androgen receptor signaling in castration-resistant prostate cancer. Proc. Natl. Acad. Sci. USA 2019, 116, 631-640. [CrossRef]

54. Han, W.; Gao, S.; Barrett, D.; Ahmed, M.; Han, D.; Macoska, J.A.; He, H.H.; Cai, C. Reactivation of androgen receptor-regulated lipid biosynthesis drives the progression of castration-resistant prostate cancer. Oncogene 2018, 37, 710-721. [CrossRef] [PubMed]

55. Centenera, M.M.; Scott, J.S.; Machiels, J.; Nassar, Z.D.; Miller, D.C.; Zininos, I.; Dehairs, J.; Burvenich, I.J.G.; Zadra, G.; Chetta, P.; et al. ELOVL5 is a critical and targetable fatty acid elongase in prostate cancer. Cancer Res. 2021, 81, 1704-1718. [CrossRef]

56. Abudurexiti, M.; Zhu, W.; Wang, Y.; Wang, J.; Xu, W.; Huang, Y.; Zhu, Y.; Shi, G.; Zhang, H.; Zhu, Y.; et al. Targeting CPT1B as a potential therapeutic strategy in castration-resistant and enzalutamide-resistant prostate cancer. Prostate 2020, 80, 950-961. [CrossRef] [PubMed]

57. Audet-Walsh, É.; Vernier, M.; Yee, T.; Laflamme, C.; Li, S.; Chen, Y.; Giguère, V. SREBF1 Activity Is Regulated by an AR/mTOR Nuclear Axis in Prostate Cancer. Mol. Cancer Res. 2018, 16, 1396-1405. [CrossRef]

58. Ogretmen, B. Sphingolipid metabolism in cancer signalling and therapy. Nat. Rev. Cancer 2018, 18, 33-50. [CrossRef]

59. Gangoiti, P.; Granado, M.H.; Alonso, A.; Goñi, F.M.; Gómez-Muñoz, A. Implication of ceramide, ceramide 1-phosphate and sphingosine 1-phosphate in tumorigenesis. Transl. Oncogenomics 2008, 3, 81-98. [PubMed]

60. Rivera, I.-G.; Ordoñez, M.; Presa, N.; Gangoiti, P.; Gomez-Larrauri, A.; Trueba, M.; Fox, T.; Kester, M.; Gomez-Muñoz, A. Ceramide 1-phosphate regulates cell migration and invasion of human pancreatic cancer cells. Biochem. Pharmacol. 2016, 102, 107-119. [CrossRef]

61. Chase, A.; Cross, N.C. Aberrations of EZH2 in cancer. Clin. Cancer Res. 2011, 17, 2613-2618. [CrossRef] [PubMed]

62. Zhao, J.C.; Yu, J.; Runkle, C.; Wu, L.; Hu, M.; Wu, D.; Liu, J.S.; Wang, Q.; Qin, Z.S.; Yu, J. Cooperation between Polycomb and androgen receptor during oncogenic transformation. Genome Res. 2012, 22, 322-331. [CrossRef]

63. Fong, K.W.; Zhao, J.C.; Kim, J.; Li, S.; Yang, Y.A.; Song, B.; Rittie, L.; Hu, M.; Yang, X.; Perbal, B.; et al. Polycomb-Mediated Disruption of an Androgen Receptor Feedback Loop Drives Castration-Resistant Prostate Cancer. Cancer Res. 2017, 77, 412-422. [CrossRef] [PubMed]

64. Chng, K.R.; Chang, C.W.; Tan, S.K.; Yang, C.; Hong, S.Z.; Sng, N.Y.; Cheung, E. A transcriptional repressor co-regulatory network governing androgen response in prostate cancers. Embo. J. 2012, 31, 2810-2823. [CrossRef] [PubMed] 
65. Wiederschain, D.; Susan, W.; Chen, L.; Loo, A.; Yang, G.; Huang, A.; Chen, Y.; Caponigro, G.; Yao, Y.M.; Lengauer, C.; et al. Single-vector inducible lentiviral RNAi system for oncology target validation. Cell Cycle 2009, 8, 498-504. [CrossRef]

66. Ugalde-Olano, A.; Egia, A.; Fernandez-Ruiz, S.; Loizaga-Iriarte, A.; Zuniga-Garcia, P.; Garcia, S.; Royo, F.; Lacasa-Viscasillas, I.; Castro, E.; Cortazar, A.R.; et al. Methodological aspects of the molecular and histological study of prostate cancer: Focus on PTEN. Methods 2015, 77, 25-30. [CrossRef]

67. Carracedo, A.; Weiss, D.; Leliaert, A.K.; Bhasin, M.; de Boer, V.C.; Laurent, G.; Adams, A.C.; Sundvall, M.; Song, S.J.; Ito, K.; et al. A metabolic prosurvival role for PML in breast cancer. J. Clin. Investig. 2012, 122, 3088-3100. [CrossRef] [PubMed]

68. Wang, Q.; Carroll, J.S.; Brown, M. Spatial and temporal recruitment of androgen receptor and its coactivators involves chromosomal looping and polymerase tracking. Mol. Cell 2005, 19, 631-642. [CrossRef] [PubMed] 